\title{
Daya Tarik Wisata Waduk Panji Sukarame Sebagai Objek Wisata di Kota Tenggarong
}

\author{
Sabalius Uhai ${ }^{1}$, Eman Sukmana ${ }^{2}$, A Rinto Dwiatmojo ${ }^{3}$ Egi Saltia Anggriawan ${ }^{4}$, Firman Sinaga ${ }^{5}$
}

1,2,4Program Studi UPW \& 3Perhotelan Jurusan Pariwisata POLNES

${ }^{5}$ Institut Pariwisata dan Bisnis International

${ }^{1}$ sabaliusuhai@polnes.ac.id² emansukamana@polnes.ac.id, ${ }^{3}$ rinto_dwiatmojo@polnes.ac.id ${ }^{4}$ egisaltia@gmail.com,

\begin{tabular}{|l|l|}
\hline ABSTRACT & ARTICLE \\
The purpose of this study was to determine the tourist attraction in Waduk Panji & HISTORY \\
Sukarame. Tenggarong City has one of the mainstay tourist destinations in East & Submitted:28.06.2021 \\
Kalimantan, one of which is the Waduk Panji Sukarame as a tourist attraction, as a & Revised:29.06.2021 \\
tourist attraction and object, it is necessary to hold a good management process so that & Accepted:08.08.2021 \\
visitors become interested in coming to the place. The purpose of this study is to find & Online first:04.01.2022 \\
out what tourist attractions are in the Waduk Panji Sukarame Tenggarong, Kutai & \\
Kartanegara Regency, East Kalimantan. The research method used is the descriptive \\
qualitative research method. The data collected is through direct observation and \\
interviews with the managers of the Waduk Panji Sukarame. Waduk Panji Sukarame \\
has natural attractions, namely, it has an orchid garden and has artificial gazebo tours, \\
colorful bridges, unique toilets, flying fox, duck bikes, viewing towers, playgrounds. \\
The Waduk Panji Sukarame has a tourist attraction and is worthy as a tourist attraction. \\
Tartural tourism, \\
artificial tourism, \\
Waduk Panji Sukarame
\end{tabular}




\section{Pendahuluan}

Kota Tenggarong adalah sebuah kota dimana tempat Kesultanan Kutai Kartanegera Ing Martadipura pernah Berjaya. Peninggalan masa lalu dari kesultanan ini dapat menjadi daya tarik tersendiri jika ingin berkunjung ke Kota Tenggarong, bahkan Kota Tenggarong juga diberikan penamaan sebagai kota "Raja". Kota Tenggarong memiliki wilayah yang luas dan hampir setiap kecamatan memiliki tempat wisata yang terkenal, mulai kecamatan Kota Bangun hingga kecamatan Samboja. Di Kota Tenggarong miliki tempat wisata terkenal Museum Mulawarman, Pulau Kumala, Ladang Budaya (Ladaya), Waduk Panji.

Waduk Panji adalah sebuah tempat wisata yang cukup menarik untuk dikunjungi. Pengembangan objek wisata Waduk Panji sangat diperlukan untuk menjadi tempat wisata yang lebih baik secara khusus dalam keterlibatan masyarakat sekitar tempat wisata (Hafni KhairunnisaTrias Shofi Nur'aini, 2020). Kurang dikembangakan secara maksimal(Bibin, 2020). Jika tempat wisata tidak dirawat dengan baik akan berpengaruh pada penurunan jumlah kunjungan (Faikar Adam Wiradiputra, 2016). Daya tarik wisata sangat berpengaruh terhadap kepuasan para pengunjung yang datang (Hary Hermawan, 2017). Supaya dapat memberikan hasil yang diharapkan oleh para pengunjung oleh karena itu para pekerja pada bidang pariwisata harus dibekali dengan uji kompetensi pariwisata (Nina Mistriani; Aletta Dewi Maria; Vera Damayanti, 2020). Peningkatan jumlah pengunjung juga berpengaruh terhadap penghasilan warga sekitar tempat wisata (Hary Hermawan, 2016). Dalam pengembangan selanjutnya pihak Waduk Panji Sukarame harus melibat masyarakat budaya dengan tujuan sebagai penambah daya tarik wisata (Sukmana, 2019).

Kehadiran Waduk Panji sebagai objek wisata perlu diperkenalkan ke pihak luar lewat promosi yang dilakukan oleh pihak pengelola Waduk Panji Sukarame(Rinto;, 2019). Saat ini karena kondisi pandemik sehingga membuat pengelola mengalami kesulitan dalam mengelola tempat wisata ini karena terbatasnya dana. Sumber pemasukan dari tempat ini adalah dari para pengunjung yang datang ke tempat ini. Selain masalah perawatan pengelola juga mengalami kesulitan dalam mempromosi daya tarik wisata yang ada di Waduk Panji Sukarame karena terbatas pendanaan dalam melakukan kegiatan promosi.

Berdasarkan pemaparan diatas tujuan dari penelitian ini adalah untuk memetakan potensi wisata yang ada di Waduk Panji Sukarame, selain itu juga membantu dalam upaya untuk mempromosikan Waduk Panji Sukarame Tenggarong. Semoga dengan dilakukan pemetaan potensi di Waduk Panji Sukarame Tenggarong membuat tempat ini menjadi tujuan wisata bagi warga Tenggarong dan sekitarnya yakni Kota Samarinda, Balikpapan, Bontang dan Kutai Barat, bahkan dapat menjadi wisata andalan di kota ini. Membuat event di tempat wisata dapat menjadi daya tarik untuk mendatangkan para pengunjung (Sabalius Uhai, 2021).

\section{Tinjauan Pustaka Pengertian Pariwisata}

Pariwisata dapat ditinjau dari berbagai sudut pandang dan tidak memiliki batasan-batasan yang pasti. Para ahli pariwisata banyak yang mengungkapkan definisi pariwisata dari berbagai sudut pandang, namun dari berbagai definisi tersebut memiliki makna yang sama. Berdasarkan Peraturan Pemerintah No.50 tahun 2011 Kepariwisataan adalah keseluruhan kegiatan yang terkait dengan pariwisata dan bersifat multidimensi serta multidisiplin yang muncul sebagai wujud kebutuhan setiap orang dan negara serta interaksi antara wisatawan dan masyarakat setempat, sesama wisatawan, pemerintah, pemerintah daerah, dan pengusaha.

Apabila ditinjau secara etimologi (Oka A Yoeti, 2008) istilah pariwisata sendiri berasal dari bahasa sanksekerta yang memiliki persamaan makna tour, yang berarti berputar-putar dari suatu tempat ke tempat lain. Hal ini didasarkan pada pemikiran bahwa kata "pariwisata" terdiri dari dua suku kata yaitu "Pari" dan "Wisata". Pari bermakna banyak, berkali-kali, berputar-putar, lengkap, wisata berarti perjalanan, bepergian. Adapun definisi pariwisata lain yang diungkapkan oleh ahli pariwisata. Menurut Hunziker dan Kraft (A.J. Muljadi, 2009). mengungkapkan bahwa pariwisata adalah keseluruhan hubungan dan gejalagejala yang timbul dari adanya orang asing dan perjalanannya itu tidak untuk bertempat tinggal menetap dan tidak ada hubungan dengan kegiatan untuk mencari nafkah. Sehingga dalam melakukan perjalanannya tersebut hanya mencari hal-hal yang sesuai dengan keinginan dan kebutuhannya. Sementara Sugiama, (2011) mengungkapkan bahwa pariwisata adalah rangkaian aktivitas, dan penyediaan layanan baik untuk kebutuhan atraksi wisata, transportasi, akomodasi, dan layanan lain yang ditujukan untuk memenuhi 
kebutuhan perjalanan seseorang atau sekelompok orang. Perjalanan yang dilakukannya hanya untuk sementara waktu saja meninggalkan tempat tinggalnya dengan maksud beristirahat, berbisnis, atau untuk maksud lainnya.

Berdasarkan seluruh definisi di atas dapat disimpulkan bahwa pariwisata adalah kegiatan yang dilakukan dengan meninggalkan tempat tinggalnya ke daerah tujuan wisata untuk sementara waktu dan bukan untuk menetap. Kegiatan perjalanannya bertujuan untuk menikmati layanan dan fasilitas yang dibutuhkan selama berada di luar tempat tinggalnya.

\section{Objek dan Daya Tarik Wisata}

Objek dan daya tarik wisata adalah suatu bentukan dan fasilitas yang berhubungan, yang dapat menarik minat wisatawan atau pengunjung untuk datang ke suatu daerah atau tempat tertentu. Daya tarik yang tidak atau belum dikembangkan merupakan sumber daya potensial dan belum dapat disebut sebagai daya tarik wisata, sampai adanya suatu jenis pengembangan tertentu. Objek dan daya tarik wisata merupakan dasar bagi kepariwisataan. Tanpa adanya daya tarik di suatu daerah atau tempat tertentu, kepariwisataan sulit untuk dikembangkan. Dalam Undang-undang No. 9 tahun 1990 tentang kepariwisataan disebutkan bahwa objek dan daya tarik wisata adalah suatu yang menjadi sasaran wisata terdiri atas:

Objek dan daya tarik wisata ciptaan Tuhan Yang Maha Esa, yang berwujud keadaan alam, flora, danfauna. Objek dan daya tarik wisata hasil karya manusia yang berwujud museum, peninggalan purbakala, peninggalan sejarah, seni dan budaya, wisata agro, wisata petualangan alam, taman rekreasi, dan komplek hiburan. Objek dan daya tarik wisata menurut Direktorat Jenderal Pemerintah di bagi menjadi 3 macam, yaitu:

1) Objek Wisata Alam

Objek wisata alam adalah sumber daya alam yang berpotensi serta memiliki daya tarik bagi pengunjung, baik dalam keadaan alami maupun setelah ada usaha budi daya. Potensi objek wisata alam dapat dibagi menjadi empat kawasan, yaitu:

a. Flora dan fauna.

b. Keunikan dan kekhasan ekosistem, misalnya ekosistem pantai dan ekosistem hutan bakau. Gejala alam, misalnya kawah, sumber air panas, air terjun dan danau.

c. Budidaya sumber daya alam, misalnya sawah, perkebunan, peternakan, usaha perikanan.

2) Objek Wisata Sosial Budaya

Objek wisata social budaya dapat di manfaatkan dan dikembangkan sebagai objek dan daya tarik wisata meliputi museum, peninggalan sejarah, upacara adat, seni pertunjukkan, dan kerajinan.

3) Objek Wisata Minat Khusus

Objek wissata minat khusus merupakan jenis wisata yang baru di kembangkan di Indonesia. Wisata ini lebih diutamakan pada wisatawan yang mempunyai motivasi khusus. Dengan demikian, biasanya para wisatawan harus memiliki keahlian. Contohnya: berburu, mendaki gunung, arung jeram, tujuan pengobatan, agrowisata, dan lain-lain. Perencanaan dan pengelolaan objek dan daya tarik wisata alam, sosial budaya, maupun objek wisata minat khusus harus berdasarkan pada kebijakan rencana pembangunan nasional maupun regional. Jika kedua kebijakan rencana tersebut belum tersusun, tim perencana pengembangan objek daya tarik wisata harus mampu mengasumsikan rencana kebijakan yang sesuai dengan areayang bersangkutan.

Suatu obyek wisata dapat menarik untuk dikunjungi oleh wisatawan harus memenuhi syarat-syarat untuk pengembangan daerahnya, menurut Maryani (1991:11) syarat-syarat tersebut adalah:

1. What to see

Di tempat tersebut harus ada obyek wisata dan atraksi wisata yang berbeda dengan yang dimiliki daerah lain. Dengan kata lain daerah tersebut harus memiliki daya tarik khusus dan atraksi budaya yang dapat dijadikan "entertainment" bagi wisatawan. What to see meliputi pemandangan alam, kegiatan kesenian, dan atraksi wisata

2. What to do

Di tempat tersebut selain banyak yang dapat dilihat dan disaksikan, harus disediakan fasilitas rekreasi yang dapat membuat wisatawan betah tinggal lama di tempat itu.

3. What to buy

Tempat tujuan wisata harus tersedia fasilitas untuk berbelanja terutama barang souvenir dan kerajinan rakyat sebagai oleh-oleh untuk di bawa pulang ke tempat asal. 
4. What to arrived

Di dalamnya termasuk aksesbilitas, bagaimana kita mengunjungi obyek wisata tersebut, kendaraan apa yang akan digunakan, dan berapa lama tiba ketempat tujuan wisata tersebut.

5. What to stay

Bagaimana wisatawan akan tinggal untuk sementara selama dia berlibur di obyek wisata itu.

Diperlukan penginapan-penginapan baik hotel berbintang atau hotel non berbintang dan sebagainya.

Selain itu pada umumnya daya tarik suatu objek wisata berdasarkan atas:

a) Adanya sumber daya yang dapat menimbulkan rasa senang, indah, nyaman, dan bersih.

b) Adanya aksesibilitas yang tinggi untuk dapat mengunjunginya.

c) Adanya ciri khusus atau spesifikasi yang bersifat langka.

d) Adanya sarana dan prasarana penunjang untuk melayani para wisatawan yang hadir.

e) Objek wisata alam mempunyai daya tarik tinggi karena keindahan alam pegunungan, sungai, pantai, pasir, hutan, dan sebagainya.

f) Objek wisata budaya mempunyai daya tarik tinggi karena memiliki nilai khusus dalam bentuk atraksi kesenian, upacara adat, nilai luhur yang terkandung dalam suatu objek buah karya manusia pada masa lampau.

Perkembangan suatu kawasan wisata juga tergantung pada apa yang dimiliki kawasan tersebut untuk dapat di tawarkan kepada wiatawan. Hal ini tidak dapat di pisahkan dari peranan para pengelola kawasan wisata. Dalam Oka A. Yoeti (1997:165) berpendapat bahwa berhasilnya suatu tempay wisata hingga tercapainya industri wisata sangat tergantung pada tiga A (3A), yaitu atraksi (attraction), mudah dicapai (accesibility), dan fasilitas (amenities).

\section{1) Atraksi (attraction)}

Atraksi wisata yaitu sesuatu yang dipersiapkan terlebih dahulu agar dapat dilihat, dinikmati dan yang termasuk dalam hal ini adalah: tari-tarian, nyanyian kesenian rakyat tradisional, upacara adat, dan lainlain. Menurut Oka A. Yoeti (Oka A Yoeti, 1997) tourism disebut attractive spontance, yaitu segala sesuatu yang terdapat di daerah tujuan wisata yang merupakan daya tarik agar orang-orang mau datang berkunjung ke suatu tempat tujuan wisata diantaranya adalah:

a. Benda-benda yang tersedia dan terdapat di alam semesta, yang dalam istilah Natural Amenities. Termasuk kelompok ini adalah:

1) Iklim contohnya curah hujan, sinar matahari, panas, hujan, dan salju.

2) Bentuk tanah dan pemandangan contohnya pegunungan, perbukitan, pantai, air terjun, dan gunungapi.

3) Hutan belukar.

4) Flora danfauna, yang tersedia di Cagar alam dan daerah perburuan.

5) Pusat-pusat kesehatan, misalnya: sumber air mineral, sumber air panas, dan mandi Lumpur . Dimana tempat tersebut diharapkan dapat menyembuhkan macam-macam penyakit.

b. Hasil ciptaan manusia (man made supply). Kelompok ini dapat dibagi dalam empat produk wisata yang berkaitan dengan tiga unsur penting yaitu historical (sejarah), cultural (budaya), dan religious (agama).

1) Monumen bersejarah dan sisa peradaban masa lampau (artifact)

2) Museum, art gallery, perpustakaan, kesenianrakyat dan kerajian tangan.

3) Acara tradisional, pameran, pestival, upacara naik haji, pernikahan, khitanan, dan lain-lain.

4) Rumah-rumah ibadah, seperti mesjid, candi, gereja, dan kuil.

2) Aksesibilitas (accesibility)

Aktivitas kepariwisataan banyak tergantung pada transportasi dan komunikasi karena faktor jarak dan waktu yang sangat mempengaruhi keinginan seseorang untuk melakukan perjalanan wisata. Unsur yang terpenting dalam aksesbilitas adalah transportasi, maksudnya yaitu frekuensi penggunaannya, kecepatan yang dimilikinya dapat mengakibatkan jarak seolah-olah menjadi dekat.

Selain trasnportasi yang berkaitan dengan aksesbilitas adalah prasarana meliputi jaln, jembatan, terminal, stasiun dan bandara. Prasarana ini berfungsi untuk menghubungkan suatu tempat dengan tempat yang lain. Keberadaan prasarana transportasi akan mempengaruhi laju tingkat transportasi itu sendiri. Kondisi 
prasarana yang baik akan membuat laju transportasi optimal.

3) Fasilitas (amenities)

Fasilitas pariwisata tidak akan terpisah dengan akomodasi perhotelan. Karena pariwisata tidak akan pernah berkembang tanpa penginanapan. Fasilitas wisata merupakan hal-hal penunjang terciptanya kenyamanan wisatawan untuk dapat mengunjungi suatu daerah tujuan wisata. Adapun sarana-sarana penting yang berkaitan dengan perkembangan pariwisata adalah sebagai berikut:

1) Akomodasi Hotel

2) Restoran

3) Air Bersih

4) Komunikasi

5) Hiburan

6) Keamama

\section{Metodologi}

A. Lokasi Penelitian

Lokasi penelitian ini adalah Waduk Panji Sukarame dengan alamat Jl. Selimpat, Panji Kecamatan Tenggarong Kabupaten Kutai Kartanegara, Kalimantan Timur.

\section{B. Teknik Pengumpulan Data}

Penelitian ini diharapkan mampu menggambarkan kondisi yang sebenarnya di lapangan. Teknik pengumpulan data yang digunakan adalah wawancara dan observasi (Moleong, 2007). Pemilihan informan dilakukan dengan Purposive sampling dan snowball sampling. Pada awalnya peneliti mendatangi langsung ke Waduk Panji Sukarame dengan memperhatian dan mendata langsung potensi atau daya tarik wisata yang ada di Waduk Panji Sukarame. Selain itu dilakukan wawancara kepada pihak pengelola dan pengunjung yang datang ke tempat tersebut. Setelah semua data terkumpul lalu dianalisis dengan menggunakan metode deskriftif kualitatif.

\section{Hasil dan Diskusi}

\subsubsection{Daya Tarik Wisata Alam}

a. Taman Anggrek

Taman anggrek ini merupakan salah satu tujuan pengunjung sebagai pembelajaran atau edukasi. kita bisa mempelajari dari mulai cara menanam, memberi pupuk, serta menyiram tanaman anggrek tersebut. Taman anggrek ini buat bertujuan agar wisatawan yang datang dapat melihat dan mempelajari beberapa macam anggrek yang ada di Kalimantan timur. namun taman anggrek ini jarang ada penjaganya sehingga kita kesulitan untuk mempelajari jenis-jenis maupun cara perawatanya, kita hanya bisa menikmati saja dan berfoto-foto dengan tanaman mahal ini, untuk jenis anggrek tersebut ada kurang lebih 43 jenis tanaman anggrek. Adapun yang merawat taman adalah seorang warga yang juga tinggal di samping taman ini.

Dalam rangka budidaya tanaman anggrek maka tahapan yang dilakukan adalah:

1. Pemilihan Bibit Unggul

Salah satu hal yang penting supaya tanaman anggrek sering berbunga yaitu dengan memilih bibit unggul untuk anggrek. Bibit unggul tanaman anggrek memiliki kharakteristik antara lain; indukan anggrek memiliki jumlah bunga yang banyak, bunganya berwarna cerah dan bunganya tidak gampang layu, dan juga memiliki bunga yang besar. Selain memperhatikan bibit unggul, supaya tanaman anggre srng berbunga adalah ksehatan bibit anggrek juga perlu diperhatikan.

2. Pemilihan Lokasi Menanam Anggrek

Agar tanaman anggrek sering berbunga, perlu mempertimbangkan pemilihan lokasi menanam anggrek. Lokasi penanaman anggrek harus disesuaikan dengan kondisi habitat aslinya. Untuk menyiasati hal tersebut, bisa memasang naungan (paranet) untuk menjaga kelembapan suhu di sekitar lingkungan anggrek. Fungsi lain paranet adalah untuk mengatur besar kecilnya intensitas paparan sinar matahari, melindungi tanaman anggrek dari serangan hama penyakit dan untuk melindungi anggrek dari air hujan. 
Setiap paranet mempunyai ukuran kerapatan yang berbeda, tingkat kerapatan itu disesuaikan atas kebutuhan tanaman anggrek berdasarkan varietas anggrek dan umur anggrek. Agar tanaman anggrek sering berbunga dan subur, pemakaian paranet bisa dikelompokkan sebagai berikut:

a. Anggrek Phalaenopsis atau biasa disebut anggrek bulan membutuhkan paranet 40-45\%.

b. Anggrek Vanda membutuhkan paranet $75-100 \%$, Karena anggrek jenis ini memerlukan sinar matahari langsung untuk fase vegetatif atau pertumbuhan dan fase generatif atau masa berbunga

c. Anggrek Dendrobium membutuhkan paranet 55-75\%.

3. Kebutuhan Cahaya Matahari Untuk Berbagai Macam Jenis Anggrek

Beda jenis anggrek beda pula kebutuhan cahaya matahari-nya. Supaya tanaman anggrek sering berbunga, berikut ini kami sampaikan kebutuhan cahaya matahari berbagai macam anggrek: Pemakaian paranet juga digunakan untuk tanaman anggrek pada usia tertentu. Tanaman anggrek yang masih berbentuk seedling memakai paranet $40 \%$. Tanaman anggrek dewasa yang mau atau sudah berbunga memakai paranet 55-75\%. Kebutuhan sinar matahari tanaman anggrek.

4. Penyusunan Tanaman Anggrek

Supaya Tanaman anggrek sering berbunga perlu diperhatikan cara penyusunan tanamannya, disarankan penyusunan rak-rak anggrek diletakkan secara mendatar dengan ketinggian 1 meter dan usahakan jangan meletakkan berjenjang karena bisa mengganggu sirkulasi udara.

5. Kelembaban udara

Tanaman anggrek membutuhkn kelembaban udara di antara 60-80\%. Supaya kelembaban tetap terjaga, di bawah rak dapat dibuat kolam/kabut di dalam rumah, lindungi dengan cara pemasangan sprinkle.

6. Media tanam

Media tanam yang bagus untuk tanaman anggrek dalam pot yaitu tersusun atas 2 bagian. Untuk 1/3 bagian bawah pot diisi dengan serpihan batu bata lalu $2 / 3$ bagian sisanya memakai serbuk kayu pakis.

7. Konstruksi pot

Bentuk pot yang paling ideal dipakai adalah pot yang dibuat dari tanah liat dan memiliki banyak lubang.

8. Penyiraman

Saat cuaca panas dilakukan penyiraman sebanyak 2 kali dan apabila cuaca hujan sebaiknya tidak perlu melalukan penyiraman. Yang perlu Anda diperhatikan yaitu kadar air media, jika dirasa kelembaban air masih cukup tidak perlu dilakukan penyiraman. Waktu penyiraman disarankan sebanyak dua kali pagi dan sore.

9. Pemupukan

Syarat utama pemupukan supaya anggrek serng berbunga yaitu pemakaian pupuk dengan kadar unsur hara $\mathrm{P}$ yang tinggi. Pemupukan dapat diberikan melalui proses penyemprotan atau penyiraman bisa juga memakai pupuk slow rilis yang pemakaiannya ditaburkan.

10. Pemberian ZPT atau Hormon

Untuk menghasilkan tanaman anggrek yang sering berbunga bisa memakai ZPT atau hormon, kedua zat tersebut dapat dipakai untuk memacu proses pembungaan anggrek atau biasa disebut Giberelin. Bisa juga Anda gunakan air kelapa dengan kadar $15 \%$ (150 ml air kelapa dilarutkan dengan 1 liter air kemudian disemprotkan).

11. Pengendalian hama penyakit

Lakukan pengamatan setiap hari guna mencegah serangan hama penyakit tanaman anggrek. Sempatkan waktu untuk membershkan pot dari kotoran, gulma maupun daun-daun yang telah membusuk. Jika tanaman anggrek terserang hama gunakan insektisida, fungisida jika terserang jamur, dan bakterisida jika ada serangan bakteri.

\section{Daya Tarik Wisata Buatan}

\section{a. Gazebo}

Gazebo yang ada di Waduk Panji Sukarame di buat lebih banyak agar wisatawan juga bisa menikmati pemandangan yang asri sambil beristirahat di gazebo dan kurang lebih memiliki 7 gazebo yang terdiri dari 3 gazebo besar dan kecil. namun sayang sekali gazebo ini tidak berfungsi semuanya hanya ada 3 gazebo, keadaanya juga sangat memprihatinkan karena gazebo tersebut sudah terlihat tua dan tidak terawat serta sampah yang cukup banyak berserakan. Ada 2 gazebo yang baru saja diperbaharui yang biasa disebut warga sekitar gazebo gandeng karena 2 gazebo ini ada jembatan penghubung. Gazebo gandeng ini juga memiliki warna yang sangat unik yaitu berwarna-warni. 
Dalam sejarahnya, gazebo atau bale bukanlah sesuatu yang baru bagi masyarakat Indonesia. Sejak zaman dahulu, gazebo sering dipakai untuk duduk lesehan atau bersantai sambil membicarak an banyak hal. Berdasarkan fungsi gazebo yang sering di pergunakan untuk duduk bersantai, mengobrol dengan tetangga, melangsungkan pernikahan atau ulang tahun, atau sekedar bengong maka gazebo sering disebut sebagai bale bengong.

Namun berdasarkan perkembangannya kini, fungsi gazebo perlahan berubah menjadi aksesoris pelengkap untuk meningkatkan nilai estetika dan keindahan dari sebuah rumah. Sehigga kadang muncul anggapan-anggapan bahwa seseorang yang dirumahnya memiliki gazebo akan masuk dalam kelas tersendiri.

\section{Gambar 1 Gazebo}

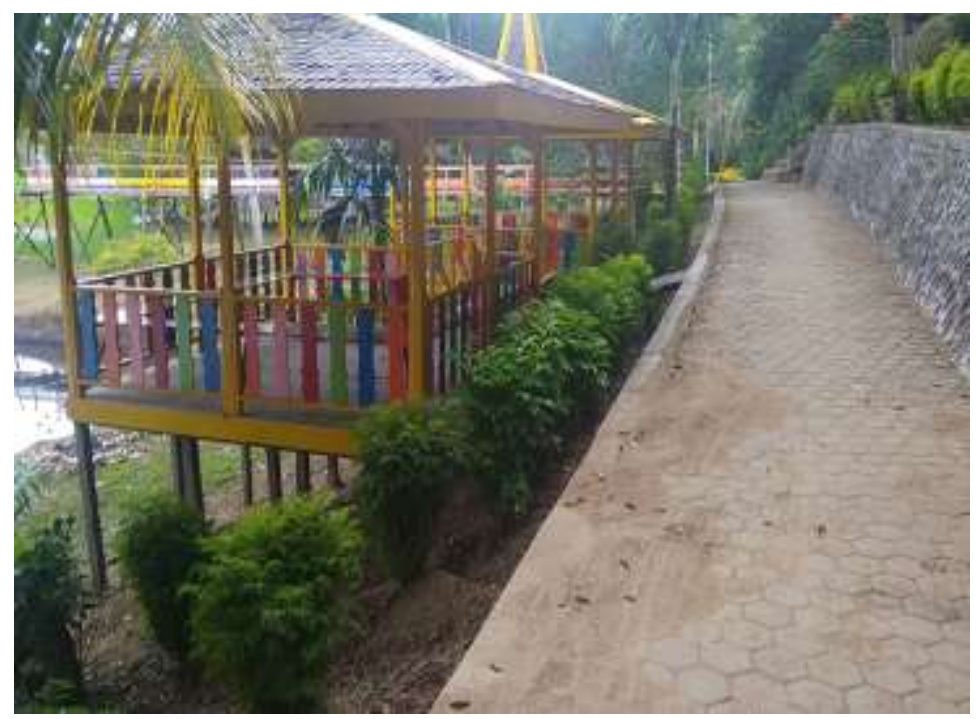

b. Jembatan Warna-Warni

Jembatan ini difungsikan untuk pegunjung yang ingin menyebrangi waduk. Jembatan ini memiliki warna yang unik yaitu warna warni. Jembatan yang terbuat dari ulin ini juga menjadi tempat favorit untuk kalangan anak muda untuk berfoto karena warna dan pemandangan yang bagus. Jembatan berada di atas waduk yang membelah waduk itu.

c. Toilet unik

Toilet yang di sediakan juga sangat banyak hanya jaraknya yang berbeda ada yang di dekat pintu masuk dan ada yang di dekat taman anggrek, tujuannya agar wisatawan tidak perlu jauh-jauh berjalan kembali ke pintu masuk hanya untuk ke toilet, keadaan WC tersebut cukup bersih dan nyaman serta tidak di pungut biaya. Jika kita ingin menggunakan WC tersebut. Ada juga satu toilet yang di desain khusus menarik karena desain ini pernah menjuarai perlombaan rias toilet di kota Tenggarong. Toilet ini memiliki bentuk unik seperti rumah adat.

Toilet merupakan hal yang sangat penting dan sensitive dimanapun kita berada. Jadi hampir disetiap tempat yang kita kunjungi pasti ada toilet yang tersedia. Namun permasalahannya ialah apakah toilet itu dalam keadaan bersih atau tidak karena biasanya toilet yang tersedia di fasilitas umum tidak begitu bersih.

Di Indonesia toilet biasanya di komersilkan atau di berikan tarif ketika kita telah selesai menggunakannya. Namun permasalahannya adalah tentang keadaan toilet yang tidak sesuai dengan pembayarannya karena kita membayar tetapi tidak ada kepuasaan kita dalam menggunakan toilet itu karena keadaannya yang sangat kotor. Namun tidak jarang ada toilet yang sesuai, nyaman dan bersih. 
Gambar 2. Toilet

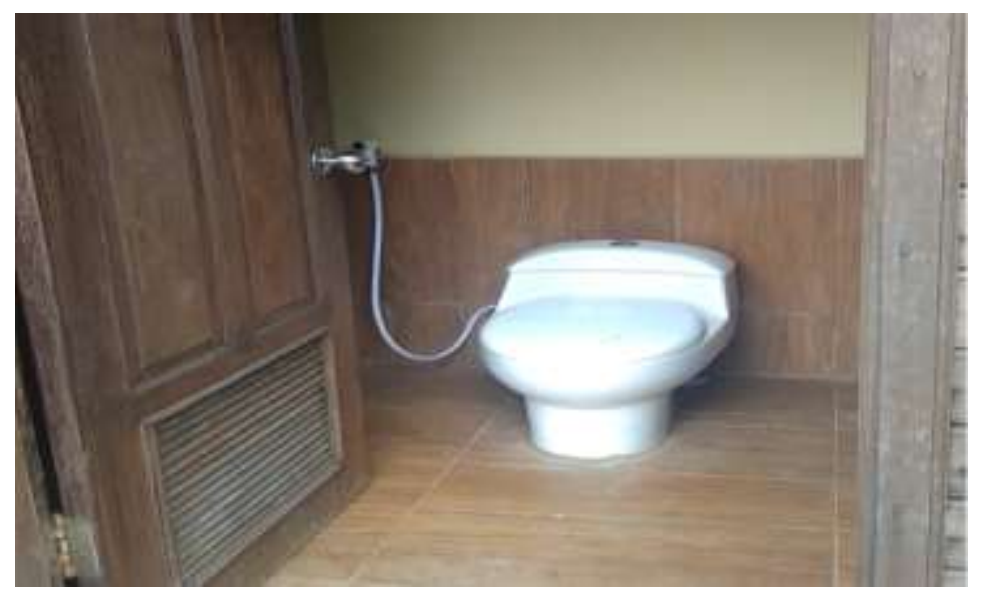

\section{d. Flying fox}

Flying fox ini beroperasi jika ada wisatawan yang ingin menikmati fasilitas ini jika saja tidak ada wisatawan atau pengunjung yang ingin menikmati flying fox ini maka tidak akan di operasikan. Flying fox memiliki panjang $150 \mathrm{~m}$ dan ketinggian $30 \mathrm{~m}$, untuk biaya dewasa Rp,15.000/org (sekali meluncur) dan untuk anakanak Rp.10.000/org (sekali meluncur), Untuk dapat menggunakan wahana flying fox ini perlu menuju puncak tertinggi. Dan flying fox akan meluncur dari ketinggian lalu melewati waduk hingga menuju pinggira waduk, ini yang menjadi perbedaan dengan wahana flying fox yang ada di Kota Tenggarong. Jika berani ketinggian maka harus mencoba sensasi yang menegangkan. Kekurangan dari flying fox ini juga tidak selalu ada penjaga yang menjaga fasilitas ini, sehingga hanya wisatawan yang beruntung saja yang dapat merasakan fasilitas ini jika ada penjaga yang menjaga.

Sepertinya tidak lengkap bila tidak ada" Flying fox". Game ini sendiri termasuk dalam kategori High Impact, sehingga dibutuhkan peralatan yang memadai, safety yang memadai dan juga tenaga operator maupun instruktur yang mempunyai pengalaman yang cukup untuk memainkan games ini. Peralatan yang dibutuhkan untuk melakukan permainan ini adalah: Carmantel, Sling Baja, Carabiner, Harnes, Pulley, Helm, dll. Cara mainnya sederhana, cukup meluncur dari ketinggian melalui tali/slingyang telah disediakan.

e. Sepeda bebek

Sepeda bebek ini merupakan salah satu fasilitas yang sangat di sukai oleh anak-anak ketika berkunjung ke Waduk Panji Sukarame ini. sepeda bebek air ini ada 13 buah sepeda yang masih berfungsi hanya 7 buah saja karena sisanya rusak dan tidak terawat. Sepeda bebek yang telah di sediakan untuk digunakan oleh para wisatawan dan jika ingin menggunakan wisatawan dapat membayar dengan harga Rp. 10,000/org mengelilingi danau selama 20 menit.

Gambar 3 Sepeda bebek

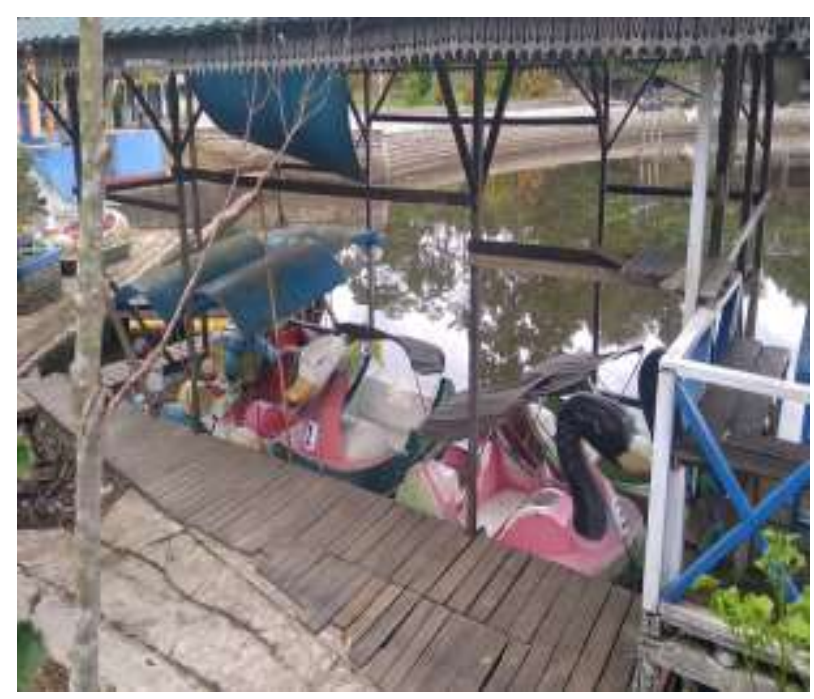


Sepeda air bebek memang favorit diantara diantara permainan air untuk kalangan anak-anak, remaja, maupun dewasa. Sepeda air fiberglass atau banyak orang menyebutnya dengan sepeda air fiberglass sering menyita banyak perhatian pengunjung. Tarif sewa air jug a tergolong murah. Jadi tidak heran jika games sepeda air, akan banyak yang, mengantri. Selain tarif harga sepeda air menikmati keindahan wahana dari atas air, juga dapat mengobrol dengan santai. Mainan sepeda air ini harus dikayuh seperti layaknya sepeda agar bisa berjalan, berjalannya pun bisa maju dan mundur, begitulah cara kerja sepeda air. Mungkin akan lebih terasa berat daripada sepeda biasa, tetapi justru itulah keseruan game sepeda air.

Bebek air fiberglass ini selain seru akan menambah kehangatan keluarga. Saat mainan bebek air bisa saling berbagi cerita banyak hal, dari mulai cerita rumah, cerita disekolah, di masyarakat, ataupun cerita suka cita lainnya. Tidak jarang para remaja pun ikut antri untuk menaiki sepeda bebek air ini. Keseruan saat berbagi cerita dengan bermain air mendukung jiwa mereka menjadi rileks. Bahkan, boneka air ini sering digunakan para remaja untuk menyatakan cintanya. Karena memang saat berada di sepeda air fiber ini begitu indah. Bisa saling menciptakan air dan bercanda gurau yangakan menambah suasana hati semakin damai. Bagi mereka yang hobi selfie, kalian bisa foto sepeda air bersama pasangan, sahabat, kerabat, dan keluarga.

Sebagai kenang-kenangan yang terabadikan lewat bidikan fotoyang menawan. Sepeda air merupakan salah satu wahana yang memiliki model atau bentuk bermacam-macam binatang. Pernahkah anda tergelitik memikirkan cara membuat sepeda air atau mungkin memikirkan bagaimana cara membuat sepeda air sederhana yang tidak serumit dengan bebek sepeda air yanganda naiki, sebenarnya cara merakit sepeda air menggunakan cetakan, cetakan tersebut merupakan rancangan sepeda air yang terlebih dahulu disesuaikan dengan model sepeda air yang diinginkan. Nah bebek air fiber ini dibuat dengan bahan dasar fiber, dengan alas fiber ringan dan lebih mudah mengapung di wisata sepeda air. Selain itu, kerajinan fiber mudah dibentuk menyerupai hewan.

f. Menara Pandang

Menara merupakan fasilitas atau sarana yang paling di sukai oleh remaja karena kita bisa menikmati pemandangan Waduk Panji Sukarame ini dari ketinggian secara menyeluruh dari atas menara ini. Menara yang ada di Waduk Panji Sukarame ini dapat dinaiki oleh wisatawan hanya saja tidak bisa ramai-ramai karena kondisi menara yang sudah tidak layak lagi di pakai. Besi yang berkarat dan sudah berlubang. Total lantai menara ada 12 lantai (tingkat). Sampai saat ini belum ada tindakan atau dana yang bisa digunakan untuk memperbaiki menara ini dari pemerintah kota . sangat disayangkan sekali memang karena potensinya yang dapat menarik wisatawan untuk mengunjungi tempat ini karena banyak sekali kekurangan fasilitas serta perawatan yang tidak dilakukan pada setiap fasilitas yang tersedia. Tower berupa tiang pancang dengan satu kaki. Tower ini di bagi menjadi 2 macam, Pertama tower yang terbuat dari pipa atau plat baja tanpa spanner, diameter antara $40 \mathrm{~cm} \mathrm{~s} / \mathrm{d} 50 \mathrm{~cm}$, tinggi mencapai 42 meter, yang dikenal dengan nama monopole. Tower Kedua lebih cenderung untuk dipakai secara personal. Tinggi tower pipa ini sangat disarankan tidak melebihi 20 meter (lebih dari itu akan melengkung). Teknis penguatannya dengan spanner. Kekuatan pipa sangat bertumpu pada spanner. Sekalipun masih mampu menerima sinyal koneksi, namun tower jenis ini tidak direkomedasi untuk penerima sinyal informatika (internetdan intranet) yang stabil, karena jenis ini mudah bergoyang dan akan mengganggu sistem koneksi datanya, sehingga komputer akan mencari data secara terus menerus (searching). Tower ini bisa dibangun pada arealyang dekat dengan pusat transmisi/ NOC $=$ Network Operation Systems (maksimal $2 \mathrm{~km}$ ), dan tidak memiliki angin kencang, serta benar-benar diproyeksikan dalam rangka emergency biaya. Dari berbagai faktayang muncul di berbagai daerah, keberadaan Tower memiliki resistensi/daya tolak dari masyarakat, yang disebabkan isu kesehatan (radiasi, anemia dll), isu keselamatan hingga isu pemerataan sosial. Hal ini semestinya perlu disosialisasikan ke masyarakat bahwa kekhawatiran pertama (ancaman kesehatan) tidaklah terbukti. Radiasinya jauh diambang batas toleransi yang ditetapkan WHO. Namun tower yang terdapat pada gambar bukanlah tower untuk sinyal namun tower ini berfungsi untuk pengunjung dapat melihat keindahan kota tenggarong khsusnya waduk panji sukarame dari ketinggian. 
Gambar 5 Menara Pandang

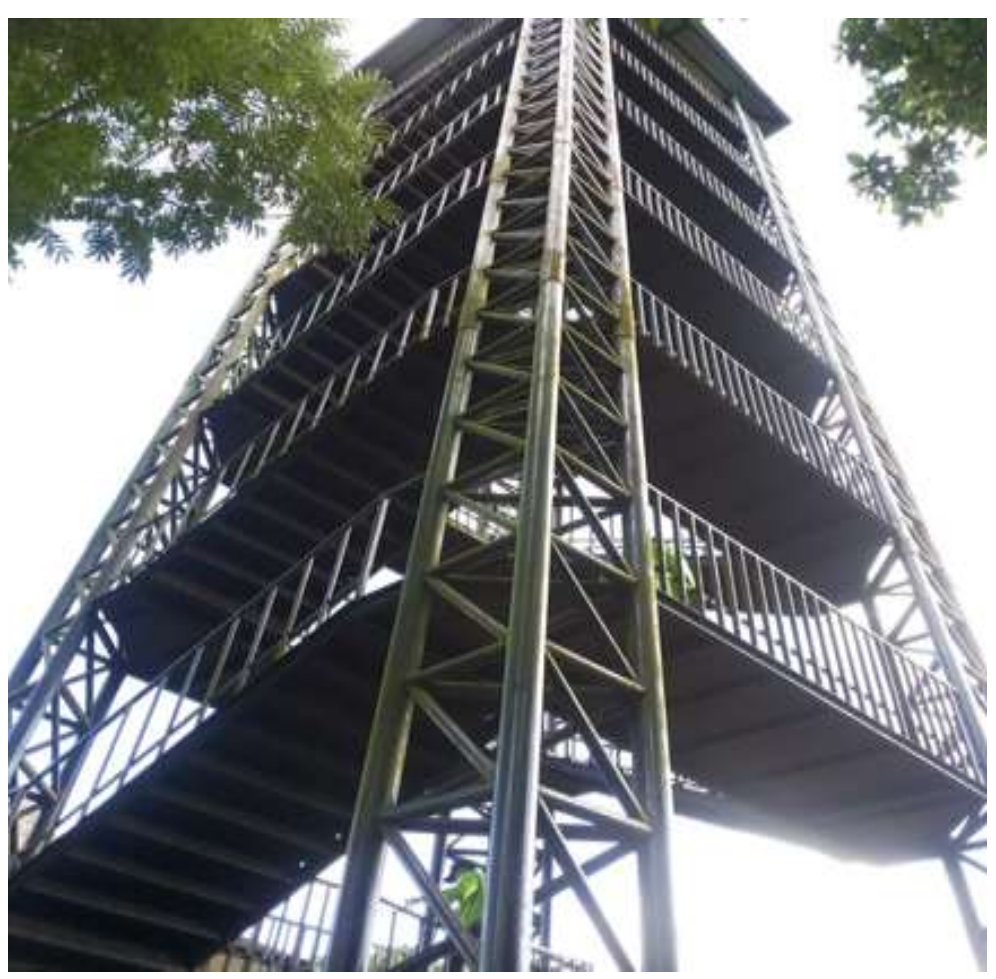

g. Lahan untuk Camping

Di Waduk Panji Sukarame juga menyediakan lahan luas untuk kegiatan camping. Biasanya lahan luas ini di gunakan oleh mahasiswa/siswa untuk melakukan kegiatan LDK, atau Family Gathering. Lahan luas ini juga menyediakan kemudahan seperti saluran air dan stop kontak untuk aluran listrik.

Gambar 4 Area Waduk Panji

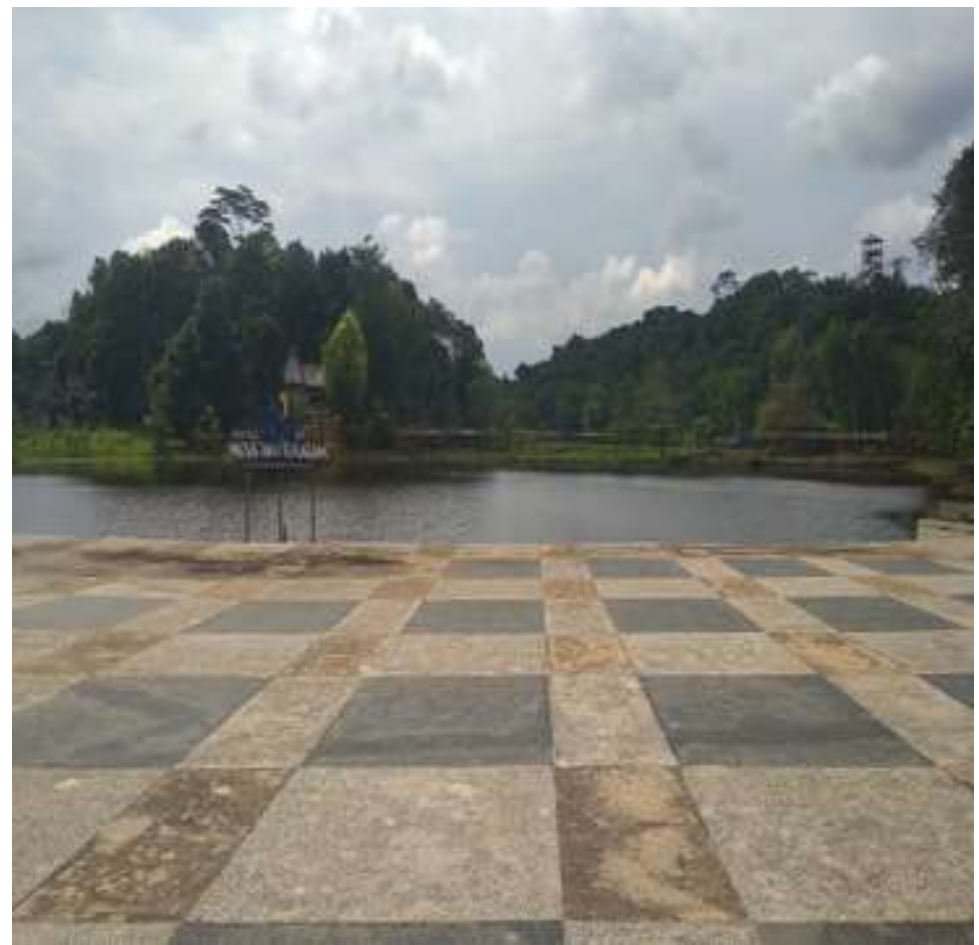




\title{
4.1.3 Daya Tarik Wisata Budaya
}

a. Kapal Kartanegara Peninggalan Sejarah

Kapal ini dulu menjadi kapal yang di gunakan oleh salah satu seorang sultanyang berkunjung ke Kutai Kartanegara. Lalu Pihak Pemerintah membawa kapal ini untuk di amankan di Waduk Panji Sukarame. Kapal ini pun juga bagus untuk berfoto. Kapal ini adalah satu-satunya daya tarik wisata budaya yang harus terus di kembangkan agar nilai-nilai budaya tidak hilang.

\section{Gambar 6 Kapal Kesultanan Kutai}

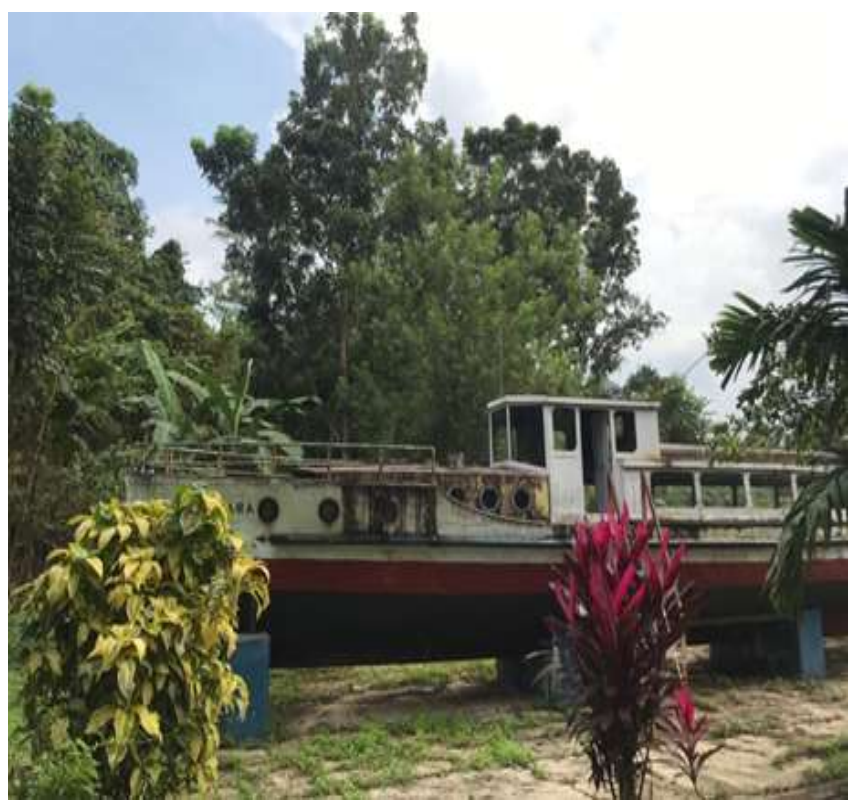

\subsubsection{Fasilitas yang ada di Waduk Panji Sukarame}

\author{
a. Gazebo \\ b. Toilet disetiap sudut \\ c. Lahan parkir yang luas \\ d. Warung makan \\ e. Flying fox \\ f. Sepeda bebek air \\ g.Menara pandang \\ h.Lahan kosong untuk camping \\ i. Taman bermain
}

\section{Kesimpulan}

Kesimpulan yang diambil dari penelitian ini adalah sebagai berikut:

1. Waduk Panji Sukarame adalah sebuah tempat objek yang layak dikunjungi.

2. Waduk Panji Sukarame menyediakan wisata alam serta wisata buatan.

3. Wisata sejarah yakni tentang peninggal Kapal Kesultanan Kutai Kartanegara. 
Edutourism Journal of Tourism Research I p-ISSN: 2686-4746 | e-ISSN: 2721-1371

\section{Author's declaration}

Authors' contributions and responsibilities

$\checkmark$ The authors made substantial contributions to the conception and design of the study.

$\sqrt{ }$ The authors took responsibility for data analysis, interpretation and discussion of results.

$\checkmark$ The authors read and approved the final manuscript.

\section{Availability of data and materials}

$\sqrt{ }$ All data are available from the authors.

\section{Competing interests}

$\sqrt{ }$ The authors declare no competing interest. 


\section{Referensi}

1) A.J. Muljadi. (2009). Kepariwisataan dan Perjalanan. PT RajaGrafindo Persada.

2) Bibin, M. A. (2020). Strategi Pengembangan Kawasan Wisata Pantai Songka Di Kota Palopo. Https://Ejurnal.Polnes.Ac.Id/, Vol. 2 No.(: TOURISM DESTINATION AND COMMUNITY DEVELOPMENT), 32. https://doi.org/https://doi.org/10.53050/ejtr.v2i01.131

3) Faikar Adam Wiradiputra, E. B. (2016). Analisis Persepsi Wisatawan Mengenai Penurunan Kualitas Daya Tarik Wisata Terhadap Minat Berkunjung. Jurnal Pariwisata, Vol. 3. No(Destinasi Pariwisata Kualitas Pelayanan Perhotelan Budaya 129. https://doi.org/https://doi.org/10.31294/par.v3i2.1561

4) Hafni KhairunnisaTrias Shofi Nur'aini. (2020). Potensi Pengembangan Wisata Berbasis Masyarakat Di Desa Banyuanyar, Boyolali. Https://Ejurnal.Polnes.Ac.Id/, Vol 2. No.(TOURISM $\begin{array}{lll}\text { DESTINATION AND COMMUNITY DEVELOPMENT), } & 55 .\end{array}$ https://doi.org/https://doi.org/10.53050/ejtr.v2i01.129

5) Hary Hermawan. (2016). Dampak Pengembangan Desa Wisata Nglanggeran Terhadap Ekonomi Masyarakat Lokal. Jurnal Pariwisata, Vol. 3 No.(Destinasi Pariwisata Kualitas Pelayanan Perhotelan Budaya Makanan), 105. https://doi.org/https://doi.org/10.31294/par.v3i2.1383

6) Hary Hermawan. (2017). PENGARUH DAYA TARIK WISATA, KESELAMATAN, DAN SARANA WISATA TERHADAP KEPUASAN SERTA DAMPAKNYA TERHADAP LOYALITAS WISATAWAN: Studi Community Based Tourism di Gunung Api Purba $\begin{array}{llllll}\text { Nglanggeran. } \quad \text { Media Wisata, } & \text { Vol. } & \text { 17. Pariwisata), } & 562 .\end{array}$ https://doi.org/https://doi.org/10.36276/mws.v15i1.213

7) Moleong, L. J. (2007). Metodologi Penelitian Kualitatif(edisi revisi). (Revisi). Rosda Karya.

8) Nina Mistriani; Aletta Dewi Maria; Vera Damayanti. (2020). Pentingnya Pelaku Industri Pariwisata Dibekali Uji Kompetensi Lewat Daring untuk Meningkatkan SDM Pariwisata di Indonesia. Edutourism, Vol. 2 No.(TOURISM DESTINATION AND COMMUNITY DEVELOPMENT), 32. https://doi.org/https://doi.org/10.53050/ejtr.v2i01.127

9) Oka A Yoeti. (1997). Perencanaan dan Pengembangan Pariwisata. PT. Pradnya Paramitha.

10) Oka A Yoeti. (2008). Pemasaran Pariwisata. PT. Pradnya Paramitha.

11) Rinto; D. S. K. I. W. S. A. N. I. N. (2019). STRATEGI PROMOSI KEBUN RAYA UNMUL SAMARINDA TERHADAP TINGKAT KUNJUNGAN WISATAWAN. Edutourism, Vol.01 No.(TOURISM DESTINATION AND COMMUNITY DEVELOPMENT). https://doi.org/https://doi.org/10.53050/ejtr.v1i01

12) Sabalius Uhai, F. Si. (2021). Manajemen Event di Desa Wisata. Literasi Nusantara. www.penerbitlitnus.co.id

13) Sukmana, E. H. B. T. H. (2019). Analisis Potensi Wisata Berbasis Budaya dengan Pendekatan Community Based Tourism (CBT) di Desa Budaya Lung Anai, Kutai Kartanegara. Edutourism, Vol.1 No.(TOURISM DESTINATION AND COMMUNITY DEVELOPMENT), 1. https://doi.org/https://doi.org/10.53050/ejtr.v1i2.122 